\title{
NEW SIGNS AND SYMBOLS IN THE CHILDREN'S ARTISTIC EXPRESSION IN THE POST-INDUSTRIAL AGE
}

\author{
Bozena Supsakova \\ Prof. Dr. PhD., Faculty of Education KU, Ruzomberok, Slovakia, supsakova@gmail.com
}

\begin{abstract}
We have spent a number of recent years on a study and a detailed research of the child's artistic expression on a large scale of samples. This entitles us to draw your attention to at least two very important moments. Everything created by children from the age of 1 to 2 up to approximately 15 years of age we can consider the child's artistic expression. It can be expressed either by the non-geometric forms (a figure, house, tree, concrete scene) or also by the geometric abstract shapes (a circle, line, square, triangle and other polygons) which express the concrete value representation. Nowadays, modern information communication technologies have distinct influence on children and youth. Predominance of visual information over the verbal one is nowadays enhanced by the visual media and visual signs. In comparison with year 2000, young people, in their artistic expression, more and more prefer graphic symbols to verbal expressing. It is the result of onset of new communication technologies (e-mails, chatting, text messaging). A new phenomenon is that preschool, younger school and middle-school age do not his paintings now only on paper, usually leave signs and pavement markings or freely on the streets, in the sand, in nature or in digital form - computer or in a notebook. Also on the walls of buildings and concrete fences playgrounds. Young people make up the picture, leaving signs and symbols at all possible and available places - the trees, the external facades, internal walls of buildings, on school furniture. Pencil and chalk in which case confused with markers, paint, spray and other sharp instruments. Artistic expression becomes a durable, leave-on. Today, it is evident that the child's artistic expression is influenced in the socio-cultural context, multi-medially and multi-culturally. It is changed also thanks to current trends in the fine arts. Children do not counter these changes, they gradually use new means of expression, change the content and the way of portraying.
\end{abstract}

Keywords: new signs and symbols, children's artistic expression, post-industrial age, picture creation in the socio-cultural context

\section{INTRODUCTION}

Child's drawing, as well as every other graphic expression or an expression through fine art is from the historical and ontogenetic point of view one of the first spontaneous expressions of individual's spiritual life. It is bound to the actual mental state, on the structure of personality. It is a certain form of creative activity, but also an utterance about one's inner life, interests, feelings, living, thoughts and life orientation. It serves for communication which is specific for a given state of a healthy, as well as mentally ill human being. It talks 
about the social environment the child lives in, about influence of up-bringing and culture, their whole life way. Drawing, shape and form are spatial projections of an experience, while colour is more or less an emotional projection of shape and form. Colour underlines the emotional side connected with experience, whereas drawing highlights the spatial perception and motive projection.

The best and even the most interesting period, from our viewpoint, concerns pre-school children and then the children of lower school age. If we omit the period of symbolic denotation, then we can speak about 4 (5) to 6 year-old children. This is the age when the graphic symbols are formed. We are convinced based on our long-term research, direct observation or analysis and synthesis of the child's artistic expression where we examined the artistic creation of children to 15 years of age on a long term basis. We draw our attention mainly to formation of signs and symbols, their importance, situating but also to the fact how the meaning is changed in the context, and how it becomes the communication tool. We were also interested in who the author is, who (what), how (to what extent) influences the creation of signs and symbols.

For the involved reader, we have chosen at least some interesting information from our research in $2000-$ 2016 (Šupšáková, 2000, 2009, 2013, 2015, and 2016). At the beginning, it is a pleasure to state that $96.7 \%$ of interviewed $5-6$ year-olds stated that they liked drawing. Only $3.3 \%$ of the children state that they do not like drawing and their negative attitude to drawing is interpreted simply: "I do not like it..." or "I cannot do it..." 5 - 6 year-olds admit they can draw animals (a dog, cat, rabbit, monkey or dinosaur). The pre-school teachers state that the children draw the dinosaurs with distinct accuracy. According to their opinion it comes from their spontaneous interest to know various kinds of dinosaurs, the environment they lived in, the way they moved. Similarly, it is interesting for them to draw space, planets, space-ships or astronauts. The second place is taken by the figures of people (princesses, mother, father, Tarzan or Ariell), houses (castles), then there come the means of transport (cars, trucks, F1 formulas and cranes). After that the children state symbols of flowers, trees, a symbol of the sun, grass, a symbol of heart and skies. It is necessary to note that the children's answers are subjective. Children approach the answers very seriously, and they attach great importance to every single word. When we asked them what they liked about drawing most of all, the order did not change much: animals (a cat, horse, bear, tiger, duck, rabbit or tortoise), then houses. After that, there come people (parents or princess), the means of transport (cars and planes). Finally, there are trees, the sun and geometric shapes.

\section{CHILD'S DRAWING AND RESEARCH}

Interest in child's artistic performance and its development dates back to the end of 19th century. The first scientific study having mapped the child's artistic development is the work of Italian art historian Corrado Ricci (1887) named L'arte dei bambini. A year later Bernard Perez published L'art et poesie chez l'enfant. At that time the artistic performance was examined from the psychological point of view and the notion "child's development in art" is specifically connected with their development in drawing (A. B. Clark, 1997; G. Kerschensteiner, 1905; G. H. Luquet, 1913; J. Sully, 1895). J. Sully connects the first drawings with play and suggests importance of game principles in the whole human culture. He highlights the fact that among the first games and plays there are many which are of aesthetical value. In the field of child's drawing study, the author restricts himself to linear, outline drawing of human figure, animals, mostly horses. Apart from some exceptions, he focuses his research on two to six-year-old children. The studies of J. Sully of year 1895 form the first attempt at continuous theoretical interpretation and examination of child's soul, child's inner world.

Most researchers orientate their research towards the child's artistic performance at an early age. (R. Arnheim, 1974; W. L. Brittain, 1979; G. A. Clark,1987, 1997; M. Cox, 1981; N. H. Freeman, 1980; C. Golomb, 1974, 1981; R. Kellogg, 1969; G. Kerchensteiner, 1905; A. M. Kindler and B. Darras, 1994; A. M. Kindler, 1999; G. H. Luquet, 1913, 1927; V. Löwenfeld, 1943 and others). As there are only a few pieces of information from a systematic research of adults' artistic creation (also due to the fact that the adults are not open enough to reveal their inner world through drawing), experts have focused on child's artistic performance. The reason is simple. Children are not restricted in their artistic expression, they are creative, spontaneous and moreover, they are willing to provide a great amount of information about themselves, their surroundings and their production. A popular German theoretician and artistic pedagogue $G$. Britsch perceived the child's artistic performance as an opportunity to express the spiritual unity of a human being and objectively existing world as early as at the beginning of this century. His theory has also significantly influenced later formation of a system for the Arts teaching, namely Bauhaus, H. Read $(1964,1967)$ but also R. Arnheim (1974, 1922).

Famous psychologist Georg Henri Luquet perceives drawing as a child's play which does not need a partner, occupies hands and sight and puts the child's inner experiences in motion in a pleasant and simple way. His theory of intellectual and visual realism $(1913,1927)$ appears to be one of the most influential reflections and 
the most popular theories. Georg Henri Luquet created a classification scheme of children's drawings on which he explains child's development in drawing as a gradual improvement of the observed reality real recreation skills. Based on his research, he classifies the respective stages following one another and provides his explanation to them: the first stage "random realism", the second stage "misunderstood realism", the third stage "intellectual realism", the fourth one "visual realism". His classification stems from the knowledge that children up to eight to nine years draw what they know about themselves, about matters and things. However, older children draw what they can see.

Victor Löwenfeld (1947) also gives the same significance to the intellectual, creative and artistic development in his works, although he highlights the expressive upbringing more. He determines several consequent stages: the first stage "scrawling", the second stage "pre-operational" with which the first "vision" appears. It is an experimental period with a large amount of changing symbols that picture the world. Thus, children find their new "schemes". V. Löwenfeld uses this notion to show a stabilized, individual way of picturing the objects at the age of seven to nine years and he describes the schematic stage as a child's ability to formulate the definitive concept of human figure and environment (V. Löwenfeld, 1947, p. 395). The third stage "visual realism" and the fourth stage "crisis in child's creative performance". Löwenfeld's theory of child's drawing according to the stages resembles Luquet's statements in many ways; he similarly tried to prove that child's drawing reflects what the child knows. V. Löwenfeld also states that a large amount of details in drawing reflects the level of child's realization of their environment. However, he gives special significance to physical, kinaesthetic experiences of children. In his opinion, omission or exaggeration of certain parts in the picture may reflect child's current state and emotions. In general, he regards drawing as a proof of their emotional comfort. He claims that children at pre-school age, who always use the same graphic portraying, are "hiding behind the symbol" in certain age and consequently "in their further behaviour they have a tendency to hide behind the social stereotypes" (Löwenfeld, 1947, p. 131). On the other hand, V. Löwenfeld assumes that "a child who reacts to purposeful experiences in a sensitive way will show this emotional sensitivity in their artistic creation" (Löwenfeld, 1947, p. 131).

Many researches, orientated towards the child's creative development, mostly towards development of picture imagination, are done by psychologists. This group of researchers is represented mainly by Jean Piaget (1970), a French psychologist, Professor at Sorbonne University, representative of genetic psychology. According to J. Piaget, a child's drawing is a form of semiotic function and it has its place in the development line between the symbolic play and picture imagination (i.e. inner imitation). The child expresses its effort to imitate reality through the picture imagination (J. Piaget, B. Inhelder, 1993).

According to this theory, at the beginning there is a set of specific reactions and later conscious operations between a subject and the surrounding world. The sets, structures and units are not static, not given in advance, but they are in motion. So they undergo the process of development, in which intellect, as well as emotions is applied. According to J. Piaget, creation of structures is regulated by two basic tendencies: assimilation, which is integration of subjects into the usual way of thinking and acting and accommodation, which is adaptation of the sense organs and mind to the outer conditions, but not supporting each other.

The following applies for research of child's drawing and its relation to reality:

1. Children create certain structures, stereotypes of graphic formations which are adapted to their perceptive and motive skills, way of perception, thinking and understanding. These stereotypes are to be treated as the formations created in an assimilation way.

2. Differentiation, segmentation and new configuration of graphic formations are to be then understood as a result of interaction between these formations and reality of the surrounding world. Formations in this process are being accommodated, adapted to outer conditions and are becoming more complicated in order to cover the new understanding of relationships.

According to J. Piaget, "not even in its initial shapes a drawing does assimilate anything and is closer, similarly like the picture idea, to the imitative accommodation. Drawing is on one hand the preparation; on the other hand it is a result of this imitative accommodation. There are a lot of interactions between a graphic picture and a picture idea (Luquet's "inner model"), as both of them stem directly from imitation" (J. Piaget and B. Inhelder, 1993, p. 59).

Jean Piaget studies development of thinking and at the same time observes the aspect of logical operation genesis creation. He stresses the primacy of personality structure. He aims at concept of relationships. Developmental segmentation of child's artistic performance into individual stages may be, in his opinion, put in relation with the characteristics of segmented development of thinking. He determines nature, developmental stages of child's artistic performance in the following way: 
1. Sensomotoric period (up to child's 2 years of age) when behavioural schemes and models of certain activities are created; thus, how to behave in the space and manipulate with objects. The first encounter with environment leaves traces in perception and attitudes of individuals.

2. Period of pre-operational thinking (from 2 to 7 or 8 years of child's age), for which egocentric thinking is typical, non-sensible thinking (inability to think through senses) and development of language. Child acts on the basis of impulses. As the time notion is unknown to them, it is necessary, according to Piaget, to expose them to direct experience based on experimentation, using the method of trial and error.

A special place in theory belongs to Rudolf Arnheim $(1974,1992)$ and his shape psychology aimed at knowing. The significant American professor of Art Psychology at the Harvard University clarifies the function of thinking in connection with perception. He enormously appreciates discovering and inventiveness of children thanks to which they remake what they can see. He perceives a picture, symbol and sign as a function of portraying. Under these terms he does not see different ways of portraying, but three functions. Portraying contains all functions at the same time; the triangle may mean danger, may represent a mountain, but also a sequence, hierarchy (R. Arnheim, 1974, p. 134).

Development of drawing is closely connected with the symbol itself, which enables children to picture the world like they see it with their eyes. According to his opinion, seeing includes always more information and sensations than is enabled by optics and physiology of the eye. In terms of optics, a picture on the retina in every moment is not more than a simple look. Even if the message is passed by the optical nerve to the brain project centres, its singularity persists. Vision is like a kaleidoscopic stream of ever changing pictures. Unless we deal with what is going on in the optical apparatus and we will move to what is going on in human brain, we are forced, according to R. Arnheim, to state that vision is nothing more than a mechanical recording of physical impulses. In his opinion, vision is being developed as a means of orientation in the environment. To fulfil this function, it may not be limited only to mechanical recording, but it must be inseparably connected with further mental functions of the mind and with the process of the world vision's creation.

R. Arnheim defines the child's artistic development in drawing as acquisition of the ability to use the graphical language. However, graphical operations are for him of higher significance. In his opinion, children have to perceive not only the structural basis of what they want to draw, but they have to think, try to find the way how to make it concrete, pass this vision to a certain medium. In his theory he clarifies and highlights the function of thinking in connection with perception. He starts with perception as the cognitive process itself and reminds that creation of pictures requires invention and imagination. According to R. Arnheim, the sight itself in a function of intelligence and perception is a cognitive process. Interpretation and meaning are inseparable parts of seeing. The base of good and effective seeing is the sensual world, something we may experience. According to it, children try to give a form to what they experience from the very beginning.

R. Arnheim is of the opinion that children draw what they can see. However, he understands seeing as a whole series of actions chosen by eye from many visual sensations creating a picture. The selection is a mental process and therefore two people who watch the same picture, do "not see" it in the same way. What each of them sees is significantly influenced by subjective experience. In connection with abstraction, he mentions a very important term "visual intelligence". According to him, "no visual experience shows the identification with reality as clearly as the one which is connected with a piece of art". To learn how to experience art means to experience everything always again. First everybody helplessly wanders in the picture and then suddenly finds a key, a way how to and what exactly to look at in the piece of art so as to be meaningful. What they saw before as a senseless pile of some elements has its explanation and meaning. Such experiences show and concurrently document that at first there is a clearer shaping of our visions, and even after that a certain order occurs in our visions. And that is the point in the whole scope of vision" (R. Arnheim, 1974, p.55).

\section{ICT HAVE DISTINCT INFLUENCE ON CHILDREN AND YOUTH}

Nowadays, modern information communication technologies (ICT) have distinct influence on children and youth. Predominance of visual information over the verbal one is nowadays enhanced by the visual media and visual signs. In comparison with year 2000, young people, in their artistic expression, more and more prefer graphic symbols to verbal expressing. It is the result of onset of new communication technologies (emails, chatting, text messaging). These forms of mutual contact, with respect to technological nature, count on expressing using abbreviations even signs (the time, charges for connection and transfer of information, etc. are saved). Thus the used vocabulary is deprived - there is an absence of interjections, clauses, etc. Instead of them, there are graphic symbols in the form of smiley faces which, in a distinct way, express 
feelings of happiness, sadness or surprise.

For the visual portraying of a feeling of happiness, the young artists very often used the symbols of sweets, presents, etc. Many of them were contented with the symbol of a smiley face, so frequently used in text messaging and in any electronic messages of nowadays. Children have explained that the smiley face is fine because it speeds up communication, saves the written and spoken word. It is understandable to everyone, especially when it is at the end of a sentence. In the form of drawing it has a nice impact. It is symbol of a positive news, mood, energy, similarly to the one on a mobile phone display. Majority of young people from our research were entirely inspired by advertising, and literally copied the symbols of commercials. Among the most popular there were sweets, advertised drinks, then smiley faces, young smiling people with big eyes, presents, texts and titles like "Take it easy" or any other advertising slogans. Artistic expression of other group of children, which was in minority, was only a little influenced by the media. Although, we can find the figures of the cartoon series, their authors "set" them to a different world and touched them up according to their fantasy. The last, the smallest group, was formed by the children whose creation was not influenced by advertising at all. Their joy of life is associated either with the family celebration or food and drinks, experience, strong emotions (sweets, presents, flowers and animals). The most frequently they stick to the figure with smile or possibly to community of other people (parents or friends) or animals.

\section{THE PROCESS OF PICTURE CREATION}

In the socio-cultural context, it is probably the most interesting to study the child's artistic expression, way of drawing, creation of signs and symbols. We assume that our findings will equally attract the reader of the publication. From numerous topics and subjects responsible for forming a more continuous view on the process of art creation and perception as the means of cognition and communication in the environment of new picture media, in conditions of multimedia and multicultural communication, we have chosen at least some interesting information.

\subsection{Interior}

Portraying the environment and the family (housing) furnishing of the room, children draw very simple linear forms: e.g. a cupboard usually is in the form of a rectangle "standing on two legs". They use the front view. It is more difficult to use the same way of portraying and draw a bed because children view it as the surface for sitting and sleeping. For this reason they prefer the bird's eye view. As they find it important to draw also the symbols of the bed's legs, they simply prolong the sides of the rectangle and continue farther without problems. They form the symbol of a chair as a link of two squares (a seat and a back-rest). The lines symbolising the legs of the chair are drawn perpendicularly to the bottom edge of the paper. They place them all four next to each other, where the lengths of all the lines are the same. The square symbolising the window in the room is portrayed only by one child because next to it there is another important symbol - a desk and a chair. These symbols are placed perpendicularly to the right side of the paper whereas the rectangle, the cupboard, is drawn perpendicularly to the bottom edge of the paper. The symbol of the door is portrayed only in one drawing, and the child gives these reasons: "There is a door - because when we sleep, it is closed." The symbol of the sun is evident in two cases. According to the children's statements, it has its place there because it makes the room full of heat and light. Artistic portraying of the rooms in the house is also worth noticing. It simultaneously points out the most important symbols, furnishing of the rooms included. At the same time, this acknowledges how and where the family members usually meet. The geometric shapes, mainly rectangles - rectangles and squares, in mutual combinations, enable the child to portray the spatial arrangement of the interior onto the paper surface. So, the front view and the ground plan coexist simultaneously.

\subsection{Game, play and toys}

In the child's artistic creation there are as usually the symbols of classic toys, a bag of toys, but also some books. Another type of symbols represents the most modern toys which simultaneously express the child's game and play. Thus, geometrical shapes resemble different cubes, modern types of cars, plush toys or a robot, they characterize the present. Exactly in the child's drawings, inter alia, we have a possibility to see the influence of TV programs, computer games and multimedia equipment approximately in 16 percent of examined artistic works. "Transparent" walls signalize game, playing in the house, which some children perceive and portray as figures in the room while taking in the television image or playing with a playing bracket. We consider the symbolic portraying of computer, video recorder connected with the television set, mostly linear, in the form of rectangles, squares or other angular polygons, using blue, black or green colour, to be a new phenomenon in the child's artistic creation, mostly by boys. Other drawings with similar themes unusually frequently lack human figure, which might show that it is an impersonal expression. Child's verbal 
commentary clarifies the content of a certain drawing: "At my grandma's I have a computer, a printing machine, a keyboard and a mouse. I play a computer game." Drawing is getting only a challenge to sit at "the drawn" table and play. It is subjective graphical expression when the children do not find it important to portray not even themselves. Their authorship (name) is a lot more stressed by bold font.

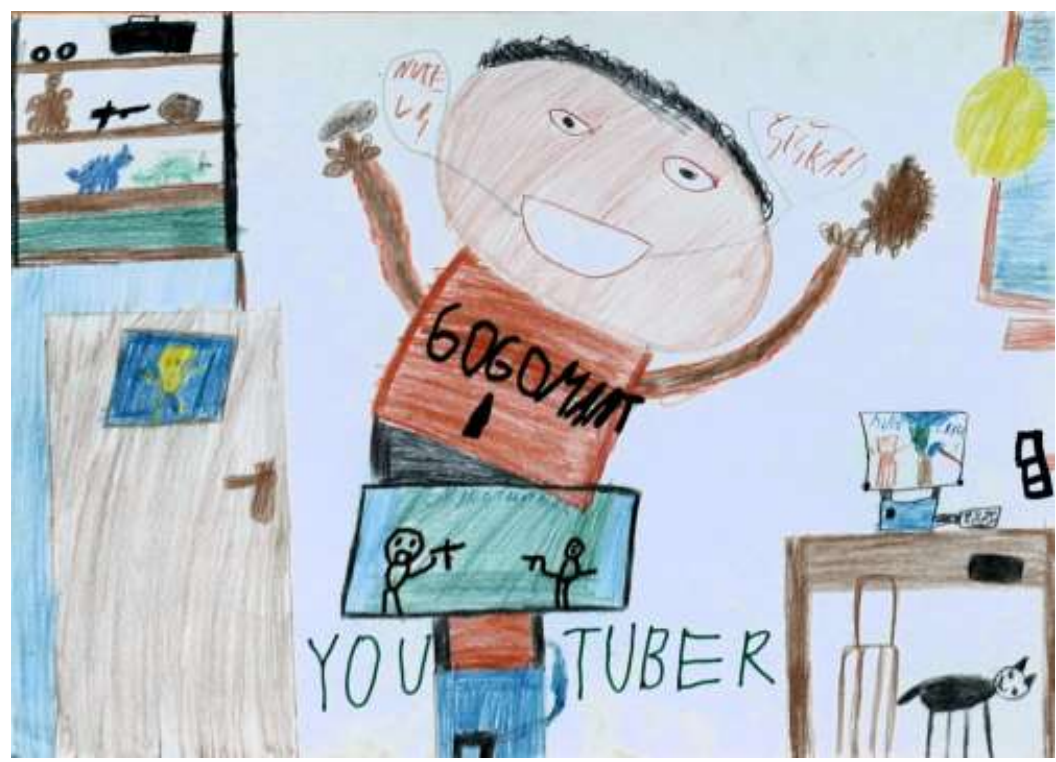

Fig. 1: At the presentation of the children's art are the dominant themes of the virtual world as You Tube, internet, online shooting...

Vice versa, in the artistic creation made by six to seven year old children there are, except of traditional signs and symbols also some new ones which portray the new quality of perception and at the same time a different way of communication (with computer). Consequently they demonstrate that children confronted with computer are in this age interested in the fact if the computers are alive, if they think or feel. Angular shapes prevail in creative child's works and individual parts portraying space of the interior are portrayed through colourful shapes, even though the used line is actually an outline. The works are full of ideas, rich in colour, dynamic, full of life, joy, where each family member has their place and work function.

\subsection{Main characters in child's drawing}

In relation to the text in previous paragraph, it is interesting also to study portraying the figure in the child's artistic expression. It is necessary to mention that a part of the children like to portray the main characters from classical fairy tales: Briar Rose, Little Red Riding Hood, Three Little Pigs, Snow-white and seven dwarfs or Pipi the Longstocking, which is usually symbolized by figure of a girl with protruding pony-tails and big boots. However, nowadays many children like to grab the comics, more modern tales or TV series and films, often on videocassettes: TV film Home Alone II, part Lost in New York has become a motive for children portraying Kevin as a main character and the other two characters represent burglars. Kid's hero is Spiderman and Iron Men, Elsa, Mimoni, Spongebob, etc. Tom and Jerry - a tomcat and a mouse, thus two animal characters popular from the TV screen, choose two children to be their friends as the main characters of a tale and at the same time as an attempt to make a stylization of an animal character. Lion King is symbolized by an animal character with markedly different head. Short lines - a symbol of lion's mane - are placed around the circle in the form of rays. Human figures appear in other drawings. "A red muzzle, an uncle, a boy and they have found a mouse...I do not remember how it is called" adds another author of the drawing.

\subsection{Trees}

Development of drawn symbols of a tree resembles the development of human figure drawings. From older expert literature we have learnt that the child experiments with portraying a tree in an early age. First they portray it as a vertical line on the bottom edge of the paper. This line has been traversed at the right angle by short lines, sometimes the angle is getting smaller. G. Britsch claims that "... drawing of a tree which originates and the branching on it is angular is a symbol for the generally acceptable ideological content, it is not a view on the tree, any projection of real directive lines on a natural object." (J. Uždil, 1976, p. 34). However, our research has shown that children usually portray and prefer a symbol of a fruit tree with fruits 
which is a significant symbol of differentiation of coniferous from deciduous tree. Another symbol characterizes portraying of a root from which the branches grow. Sometimes the branches fork, while smaller branches are as if connected to the main branch at the right angle.

We may state that the symbol of a tree appears almost in every child's artistic expression with the appropriate topic the Forest. As early as in the first chapter we had the possibility to read that its portraying is varied. Some children are satisfied with classical, so called lollipop symbol. Other children, based on the knowledge that the tree also has a tree top, first make the branches by drawing the lines in different directions. They place them to a circle which should symbolize the shape of a tree top. Small shapes of the circle that symbolize leaves "grow" from short lines which go in a ray-like form from the perimeter of a big tree - tree top. They remind us of the symbol of sun. It appears that this symbol helps to solve the problem how to portray the growing leaves. In some other drawings the tree top is portrayed in a spiral form, in the circular shape. It expresses dynamics, plot and according to the authors of the drawing "also a tree may become the source of movement". To portray the shape of a coniferous tree top, children use two refracted lines with the same distance from each other. These create rhythmically alternating short lines which change direction in a common point.

\subsection{Movement and space}

Roundabout, ship, cars and caterpillar operating as a little train are next symbols that portray the experience from the roundabouts. From our point of view, children form and stylize a symbol of the roundabout - regular child's roundabout, swing roundabout and a twister in a very interesting way. One child expresses the continuous movement through a circle from which go some interconnected lines in a ray-like way and which resembles an open umbrella from a frog's perspective. As if their physical appearance predetermined them to this view. In another artistic expression, the child draws in a parallel way to these lines another line and thus changes the arisen rectangular shape to the square resembling a seat for child. Moreover, movement, dynamics and joy are symbolized through variety of used colours.

Another drawing seems very original, where there is a circle on the bottom paper edge and some lines are going from it at the end of which they are figures portrayed in a symbolic way. The child draws the chest of the figure in the form of a square which expresses stability, solid place for sitting and the head is placed under an arch - a little roof. One more roundabout appears in this drawing - the chain one, in the form of a spiral which is a dynamic element and portrays real plot.

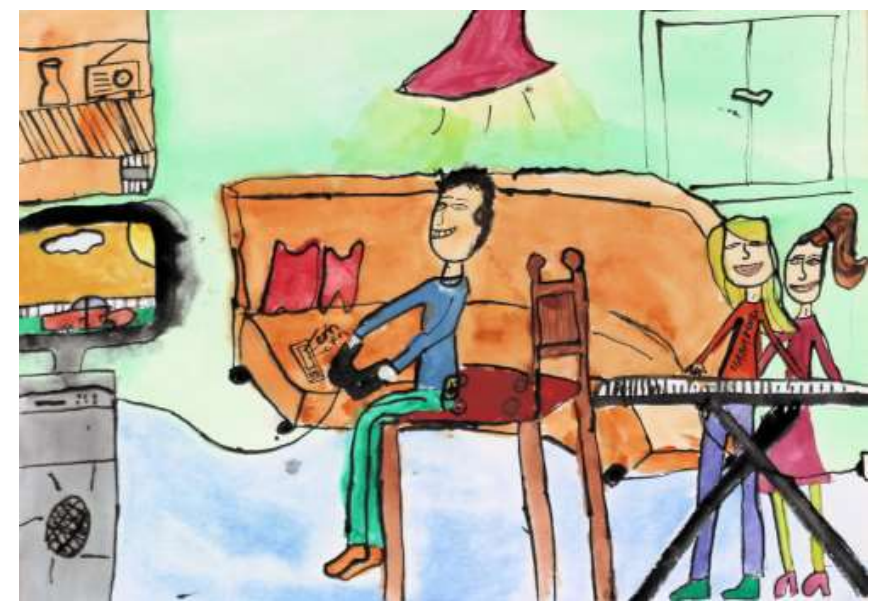

Fig. 2: Online games and entertainment are frequent motives used in children's drawings, if they express how they spend their leisure time...

A great experience is undoubtedly an indication of action that expresses swinging, movement on a big ship, represented by an oval, not as we would have expected - through two connected circles. Stylization of this symbol appears also in further art works. A view into the inner space from a bird's perspective enables seeing the figures. The child is solving also a technical problem - the movement normally portrays as gradual turning of a wheel, which is placed under the ship's hull. Braking is secured by another wheel. Both wheels are connected by a common symbol - circle. Children place them symmetrically, from both sides of the oval. Sun, as a symbol of warmth, light, the clouds and the Earth add up to the picture.

Another ship stylized through a symbol fully complies with an adult's view. The child places their ship to the real natural environment. It is portrayed from the sides, which is typical for drawing of a vessel on the water. 
Motor racing circuit attracts mostly boys' attention. The used symbols of cars have become easily readable. What is interesting is their arrangement on the paper format: lining up to the horizontal lines above each other or only to one line. There are no figures visible, which may suggest that the cars might have been parked. The car which covers the whole paper surface in the next artistic creation represents child's personal experience: "I have driven such a car", while the other cars are not that interesting and important for portraying the concrete situation.

Only one child's work does not represent a personal experience. A centipede - circles next to each other, which symbolize wagons - is moving on a solid track which is formed by two lines placed next to each other. There are some figures sitting in the wagons. The artistic creation expresses a desire to ride on this concrete centipede. Sun, clouds and crows - two circular lines in the form of a reversed wagon - bring the child to a real environment.

We have a possibility to perceive two ways of portraying. A group of children represents movement in the shape of a circle, higher number of small circles resembling threaded beads on one thread, which form something like a necklace. Such symbolic portraying of space is enough for children. They put the details of a human figure - eyes, nose, mouth, sometimes hair - in small circles, whereas the glances of all portrayed child's faces head to the receiver of the picture. In fact the portraying of figures would have required observing the principles of perspective. Except one drawing, children have avoided this problem. Probable cause is their apprehension about not managing a readable shape. Another group of children draw the figures horizontally. The drawings that symbolize figures are placed next to each other in a linear way with an indication (holding hands), but also without indication. Connecting the two lines of figures solves the artistic portraying of figure, the symbol of which is inverted. Instead of side view, we can see them from the front; they are turned approximately in 90 degrees. These and also other child's artistic creations clearly prove how important it is nowadays to study the process of picture creation, development and way of graphic portraying. The same is with graphic symbols and their significance, mostly if the child's creation aims at expressing space, perspective and movement.

\subsection{Play with geometric shapes}

Creative image is a spiritual process during which a new value and idea is formed. Connecting the visualspace thinking and artistic expression in the creative process determines development of child's creative image ability. Children present their ideas, attitudes, own system of values and hierarchy of values in a unique way, by means of colour, shapes, lines and other relationships. They make abstract pictures, however, based on unawareness of notions, they put them as late as on the seventh grade. They make shapes and lines in a different form, they put points in the groups, and they solve colourful structure of areas, whereas they prefer clear and neat colours. Children include in their pictures also block letters or other signs. Only in some artistic works, there are some older, known and already fixed symbols of flowers or a king's crown. The artistic pictures suggest certain Paper-machine, Colour picture, Ninja turtle, Special fountain geometrical. In the second group there are individual geometrical shapes scattered on the whole surface. Artistic works are of a diffusive character and pictures suggesting Balls, Colour picture, Auto-robot, Strings, Lorry with traffic lights and Carnival are created.

A source point for further activity has become a spot, which in children's eyes represents Colourful fence, Colourful bush, Fruit tree, Colourful toys, Special colourful tree, Daisy, Green tree, Ice-cream town, Flower and Labyrinth. What is interesting is the child's expression, but also their handwriting. Part of children uses the colourful surfaces, which literally adds to the black spot. They try to include the "spurs" of the sport in one, less complicated shape. They use clear and bright colours. Red, pink, blue, green and yellow surfaces prevail. Part of children also uses colourful surfaces which they border by a line and perceive as a whole. The third group of children puts the colourful surfaces directly to the spot and then draws geometrical shapes or more complicated shapes created from different refracted lines. In the last group there is a big amount of small, fine shapes stylized in different shapes (circles, short lines, arches, ovals, dots), which eventually make the spot more special in a very original way. Lining up the colourful dots shows a very sensitive attitude. Some children write their first name and, thus, writing serves as a decorative element that makes the whole picture more interesting.

\section{CONCLUSION}

Most children in pre-school age create very spontaneously. From the artistic point of view, we cannot talk exactly about creativity because their artistic expression is not sufficiently equipped with creative (sign) means or artistic techniques. On the other hand, it is very personal, fresh and sincere. Child's spontaneity vanishes around 6 to 7 years of age and unfortunately, at the age of 7 (8) years also interest in the artistic 
creation, which we estimate approximately at 40 percent. Most children start to copy what they can see and start to prefer the word as a way of their own expression in this period.

In comparison with children of pre-school and younger school age, only minor percentage of creative works are found among children of older school age, which we consider to be a minimum level of continuity from the childhood. Why isn't the artistic creativity transferred to older age? We may perhaps reason it partially by development principles, but this fact is a lot more influenced by school with its norms, rules and educational influence which prefers imitation, "teaches children to learn" and little supports creativity. Level of cognitive development at this age is predetermined by development of convergent thinking at the expense of divergent one. Also family environment, as well as classical methodology of teaching the Arts with exactly defined style of learning contributes to this fact.

Expressive perception of activity, which we find the basis of the Arts at school, confirms the strength of relationship and communication dimensions of fine arts influence.

Creative activities, but also the Arts subject itself form space for self-realization, dynamic learning of oneself and others. Especially in these modern times it is more necessary than before to support development of child's own artistic creation, as modern technologies and new visual media enforce artificial creativity on children and suppress the own (individual) creativity of each individual mostly through perception of TV images and computer signs.

Traditional aiming of research at graphic production, and especially drawing, so far has limited the space for discussion on ontogenetic development in the child's artistic expression. Some researchers, aware of this fact, start to use closer denotations in their publicised works. For example, there is development of picture imagination or a graphic symbol, which according to the technical literature, comprises all symbolizing or substituting qualities having the graphic form in the shape of a line, surface or system of graphic traces. The graphic symbol situated between the word and picture is irreplaceable. Their common feature is the graphic form but semantic value and concrete shapes are distinctly different.

The process of creation and the artistic product, as well as our further empiric knowledge show us that the child's artistic expression of nowadays is not only a demonstration of what the authors know and see in their surroundings. Knowledge that the child's artistic expression is bound to the system of symbols is important. Children literally explore and create various systems of symbols which simultaneously enable them to create their own vision of the portrayed world. As we are persuaded by some of the examples in this publication, in the child's artistic expression, their own graphic logic prevails. At an early age, children gain the ability to use the graphic language. They simultaneously develop different possibilities of expression and a different visual language.

Today, it is evident that the child's artistic expression is influenced in the socio-cultural context, multimedially and multi-culturally. It is changed also thanks to current trends in the fine arts. Children do not counter these changes, they gradually use new means of expression, change the content and the way of portraying. As their artistic expression is influenced by the environment and at different levels, it is diverse and multilateral. It is quite difficult to speak about strictly defined evolution concept of the child's artistic expression. In the ontogenetic principle, linearly understood concept of the development of the picture creation seems to be insufficient in the present day conditions. It is perhaps indicated by the content of the publication together with many illustration. The concept of the child's artistic expression is more acceptable as the concept of the "open structure" because the children at the same time develop different possibilities of expression together with the visual language.

Contemporary process of the picture imagination has to be viewed as a reflection of a civilised society. The children will change it hereafter; their view of the artistic expression and self-creation will probably be changed as well. The teachers will do the same. It comes to a certain conflict of interests which will require mutual understanding, sympathy. Therefore, it is inevitable to explore the child's artistic expression as a phenomenon and pay close attention to it in the future. Nowadays, apart from the graphic expression and imagination, tremendous fortune lies in the area not yet scientifically explored - in the spatial creation, in photography or multimedia.

\section{REFERENCE LIST}

Arnheim, R. (1974). Art and visual Perception. Berkeley - Los Angelos. 
Arnheim, R. (1992). Entropie a umění. Esej o neuspořádanosti a řádu. Praha.

Brittain, W. L. (1979). Creativity, art, and the young child. New York: MacMillan.

Clark, A. B. (1997). The child's attitude toward perspective problem. In: Studies in Education.

Cox, M. (1981). One thing behind another: Problems of representation in children's drawings. In: Educational Psychology, Vol. 1, No. 4, pp. 275-286.

Darras, B. (1996). Au commencement etait l'image: Du dessin de l'enfant a la communication de l'adulte. Paris: ESF.

Darras, B., Kindler A. M. (1996). Morphogenese et teleology des images. In: Imagies, Vol. 1, pp. 49-56.

Darras, B., Kindler, A. M. (1966). Morphogenese et teleology des images et de l'imagerie initiale. In: B. Darras, Au commencement etait l'image: Du dessin de l'enfant a la communication de l'adulte. Paris: ESF, pp. 73-94.

Davis, J. (1997). The ,U" and the wheel of „,C": development and devaluation of graphic symbolization and the cognitive approach at the Harvard Project Zero. In: A. M. Kindler (Ed.) Child development in art. Reston : NAEA, pp. 45-58.

Fortes, M. (1940). Children's drawings among the Tallensi. Africa, Vol. 13, No. 3, pp. 293-295.

Fineberg, J. (1995). Mit dem auge des kindes. Mníchov.

Freeman, N. H. (1980). Strategies of reprezentation in young children. New York.

Golomb, C. (1992). The child's creation of a pictorial world. Berkeley: University of California Press.

Goodman, N. (1968). Language of art. Indianapolis : Bobbs-Merrill.

Kellogg, R. (1969). Analyzing children's art. Palo Anto': National Press Books.

Kerschensteiner, G. (1905). Die entwicklung der zeichnerischen Begabung. Munich : Carl Gerber.

Kindler, A. M. (1995). Significance of adult input in early childhood artistic development. In: C. M. Thompson (Eds.) The visual arts and early childhood learning. Reston : NAEA, pp. 10-14.

Kindler, A. M. (1999). „From endpoints to repertoires:" A challenge to art education. In: Studies in Art Education. Vol. 40, No. 4, pp. 330-349.

Kindler, A. M. (2000). Drawing development through the lenses of age and culture. Paper presented at the 30th Annual Meeting of the Jean Piaget Society. Montreal: Canada.

Kindler, A. M., Darras, B. (1994). Artistic development in context; Emergence and development of pictorial imagery in the early childhood years. In: Visual Arts Research, Vol. 20, No. 2, pp. 1-13.

Kindler A. M., Darras, B. (1997). Map of artistic development. In: A. M. Kindler (Eds.) Child development in art. Reston : NAEA.

Kindler, A. M., Darras, B. (1997a). Development of pictorial representation: A teleology-based model. In: Journal of Art and Design Education, Vol. 16, No. 3, pp. 217-222.

Kindler, A. M., Darras, B. (1998). Culture and development of pictorial repertoires. In: Studies in Art Education, Vol. 39, No. 2, pp. 47-67.

Kindler, A. M. (1999). Rozwoj artystyczny i edukacja artystyczna. In: Plastyka i wychowanie, 1999, No. 3, pp. 26-29.

Kindler, A. M. (Eds). (1997). Child development in art. Reston : NAEA, pp. 183-192.

Löwenfeld, V. (1947). Creative and mental growth. New York: Macmillan.

Löwenfeld, V., Brittain, W. L. (1977). Tworczosc a rozwoj umyslowy dziecka. Warszawa: PWN.

Luquet, G. H. (1913). Les dessins dún enfant. Paris: Alcan.

Luquet, G. H. (1927). Le dessin enfantin. Paris: F. Alcan.

Oakleyová, A. (2003). Pohlaví, gender a společnost. Praha: Portál.

Pariser, D. (1997). Graphic development in artistically exceptional children. In: A. M. Kindler (Eds). Child development in art. Reston : NAEA, pp. 115-130. 
Pariser, D., van den Berg, A. (1997). The mind of the beholder: Some provisional doubts about the u-curve aesthetic development thesis. In: Studies in Art Education, Vol. 38, No. 3, pp. 158-178.

Peirce, C. S. (1931-1935). Collected papers. Cambridge: MA, Harvard University Press.

Piaget, J. (1950). The psychology of intelligence. New York: Harcourt Brace.

Piaget, J. (1954). The construction of reality in the child. New York: Basic Books.

Piaget, J., Inhelder, B. (1956). The child's conception of space. London: Routledge and Kegan Paul.

Piaget, J. (1970). Psychologie inteligence. Praha: SPN.

Piaget, J., Inhelder, B. (1993). Psychológia diet’ata. Bratislava: SOFA.

Read, H. (1967). Výchova umením. Praha: Odeon.

Read, H. (1964). Osudy moderního uměni. Praha: Odeon.

Reed, H. (2002). Mezi myšlenkou a vyjádřením. Praha: Herman a synové.

Roselini, D. (2001). Kresba jako nástroj poznání dítěte. Praha: Portál..

Ricci, C. (1887). L'arte dei bambini. Bologna: Zanichelli.

Sully, J. (1895). Studies of childhood. London: Longmans.

Šupšaková, B. (2000). Detský výtvarný prejav. Bratislava: DIGIT.

Šupšáková, B., Tacol, T., Čerkez, B. (2007). Art education: retrospectives, perspektives, alternatives. Ljubljana: Debora.

Šupšáková, B. (2009). Child's creative expression through fine art. Ljubljana: DEBORA.

Šupšáková, B. (2013). Detský výtvarný prejav: od čmáraníc k obrazom a ich významom. Bratislava: DOLIS.

Šupšáková, B. (2015). Vizuálna gramotnost'. Brno: TREBUN.

Šupšáková, B., Belešová, M., Szentesiová, L. (2016). Slovo a obraz v komunikácii. Brno: TREBUN.

Uždil, J. (1976). Výtvarný projev a výchova. Praha: SPN.

Uždil, J. (2002). Čáry, kliky, háky, paňáci a auta. Praha: Portál.

Vygotský, L. S. (1981). Psychológie uměni. Praha: SPN.

Willats, J. (1984). Getting the drawing to look right as well as to be right: The interaction between production and perception as a mechanism of development. In: W. R. Crosier and A. J. Chapman (Eds.) Cognitive processes in the perception of art. Amsterdam: North Holland, pp. 111-125.

Willats, J. (1997). Art and representation. Princeton : Princeton University Press.

Wilson, B., Wilson, M. (1977). An iconoclastic view of the imagery sources in the drawings of young people. In: Art Education.

Wilson, B. (1997). Child art, multiple interpretations, and conflicts of interest. In: A. M. Kindler (Eds). Child development in art. Reston : NAEA, pp. 81-95.

Wilson, B., Wilson, M. (1977). An iconoclastic view of the imagery sources in the drawings of young people. In: Art Education, Vol. 30, No. 1, pp. 5-11.

Wilson, B., Wilson, M. (1982). The case of a disappearing two-eyed profile: Or how little children influence the drawings of little children. In: Review of Research in Visual Arts Education, No. 15, pp. 19-32.

Wilson, B., Wilson, M. (1985). The artistic tower of Babel: Inextricable links between cultural and graphic development. In: Visual Arts Research, Vol. 11, No. 1, pp. 90-104.

Wolf, D. (1994). Development as growth of repertoires. In: M. F. Franklin and B. Kaplan (Eds.). Development and the arts. Hillsdale : Lawrence Erlbaum.

Wolf, D., Perry, M. (1988). From end points to repertoires: New conclusions about drawing development. In: Journal of Aesthetic Education. 